\title{
YEAR-ROUND POULTRY LITTER DECOMPOSITION AND N, P, K AND Ca RELEASE(1)
}

\author{
Christiano Santos Rocha Pitta ${ }^{(2)}$, Paulo Fernando Adami(2), Adelino

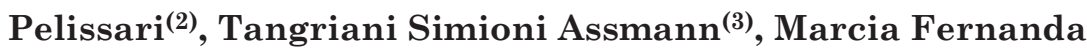 \\ Franchin $^{(3)}$, Luís César Cassol ${ }^{(3)} \&$ Laércio Ricardo Sartor $^{(2)}$
}

\begin{abstract}
SUMMARY
Poultry litter is an important nutrient source in agriculture, although little information is available regarding its decomposition rate and nutrient release. To evaluate these processes, poultry litter (PL) was applied to the soil to supply 100, 200 and $300 \mathrm{~kg} \mathrm{ha}^{-1} \mathrm{~N}$ contained in $4,953,9,907$ and $14,860 \mathrm{~kg} \mathrm{ha}^{-1} \mathrm{PL}$, respectively. The litter bag technique was used to monitor the process of decomposition and nutrient release from the litter. These bags were left on the soil surface and collected periodically (after 15, 30, 60, 90, 120, 150, 180, 210, 240, 270,300,330, and 365 days). The dry matter (DM) loss was highest (35\%) after the first 30 days of field incubation. The highest nutrient release occurred in the first 60 days on the field, when 40,34, 91, and $39 \%$, respectively, of $\mathrm{N}, \mathrm{P}, \mathrm{K}$, and Ca of the initial PL dry matter $\left(4,860 \mathrm{~kg} \mathrm{ha}^{-1}\right)$ was already released to the soil. In absolute terms, these percentages represent $40,23,134$, and $69 \mathrm{~kg} \mathrm{ha}^{-1}$ of $\mathrm{N}, \mathrm{P}, \mathrm{K}$, and Ca and these values doubled and tripled as the PL fertilization rates increased to 9,907 and $14,860 \mathrm{~kg} \mathrm{ha}^{-1}$, respectively. After one year of field incubation, the residual contents in the litter were $27,15,18$ and $30 \%$ of the initial DM, and N, P and Ca, respectively. The release rate of $K$ was the fastest and $91 \%$ of the $K$ had been released from the PL after 30 days of field incubation.
\end{abstract}

Index terms: Litter bag, filed incubation, organic fertilizer, residual contents.

(1) Received for publication in August 28, 2011 and approved in April 11, 2012.

(2) Programa de Pós-Graduação em Agronomia, Departamento de Fitossanidade, Universidade Federal do Paraná - UFPR. Rua dos Funcionários 1540, Juvevê, CEP 80035-050 Curitiba (PR). E-mails: christiano.pitta@ifpr.edu.br; paulo.adami@ifpr.edu.br; linopeli@ hotmail.com; laerciosartor@hotmail.com

(3) Programa de Pós-Graduação em Agronomia, UTFPR. Via do Conhecimento, km 1, CEP 85501-290 Pato Branco (PR). E-mails: tangriani@utfpr.edu.br; marciafranc@hotmail.com; cassol@utfpr.edu.br 


\title{
RESUMO: DECOMPOSIÇÃO E LIBERAÇÃO DE NUTRIENTES (N, P, K, Ca) DA CAMA DE AVIÁRIO
}

\begin{abstract}
Cama de aviário é uma importante fonte de nutrientes para a agricultura, porém existem poucas informações em relação à sua taxa de decomposição e liberação de nutrientes. O objetivo deste trabalho foi avaliar a taxa de decomposição e liberação de nutrientes da cama de aviário. A adubação foi realizada a fim de suprir 100, 200 e $300 \mathrm{~kg} \mathrm{ha}^{-1} \mathrm{de} \mathrm{N}$; para isso, foram aplicados ao solo 4.953, 9.907 e $14.860 \mathrm{~kg} \mathrm{ha}^{-1}$ de cama. Para monitorar o processo de decomposição e liberação de nutrientes da cama, utilizou-se a técnica dos sacos de decomposição, os quais foram deixados na superfície do solo e recolhidos após 15, 30, 60, 90, 120, 150, 180,210, 240, 270, 300, 330 e 365 dias. As maiores perdas de matéria seca (MS) (35\%) foram verificadas nos primeiros 30 dias de incubação em campo. As maiores taxas de liberação de nutrientes ocorreram nos primeiros 60 dias de incubação em campo. Nesse período, 40, 34, 91 e $39 \%$ do N, P, K e Ca encontrados na matéria seca inicial da cama $\left(4.860 \mathrm{~kg} \mathrm{ha}^{-1}\right)$ já haviam sido liberados ao solo. Em valores absolutos, essas porcentagens representam 40,23, 134 e $69 \mathrm{~kg} \mathrm{ha}^{-1} \mathrm{de} \mathrm{N}, \mathrm{P}, \mathrm{K}$ e Ca, que duplicaram e

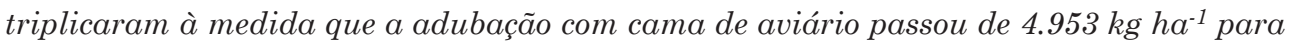
9.907 e $14.860 \mathrm{~kg} \mathrm{ha}{ }^{-1}$. Após um ano de incubação em campo, a cama apresentou residual de 27, 15,7, 18 e $30 \%$ do valor inicial de MS e teor de $\mathrm{N}$, P e Ca, respectivamente. O K apresentou a taxa de liberação mais rápida: após 30 dias de incubação em campo, 91 \% do K encontrado na cama já havia sido liberado ao solo.
\end{abstract}

Termos de indexação: sacos de decomposição, incubação a campo, adubação orgânica, teor residual.

\section{INTRODUCTION}

Poultry production is becoming increasingly important as a major income source for many farmers in southern Brazil, where Paraná is leading in poultry production and export. The southwest region of the state accounts for $22 \%$ of poultry production (Zanchet, 2008). With the concentrated, rapid growth of the sector, waste production and its consequent problems are on the rise, since poultry production operations (feed mills and poultry and slaughter houses) are often regionally concentrated, so litter production may exceed the crop nutrient requirements of the producing and surrounding farms and jeopardize the environment.

The application of poultry litter to crop lands is on the one hand important as an environmentallyfriendly means of waste disposal and on the other hand as a valuable source of plant nutrients to maintain or restore soil fertility. However, for environmentally and economically sound applications of poultry litter (PL), it is crucial to know the decomposition rate of and nutrient release from the litter. This information allows a better management of levels and timing of litter application to synchronize plant requirements and litter nutrient release in order to avoid any environmental hazard, to enhance soil fertility and to use this manure resource optimally. Moreover, based on PL decomposition dynamics and nutrient release rates it is possible to evaluate residual effects of poultry litter and accordingly, to finetune recommendations of fertilizer levels for the subsequent crops.

A substantial number of studies have been conducted to determine PL effects on agriculture and environment. Some of these studies show advantages such as: high nutrient concentration (Zhang et al., 2002), increase in total soil carbon and organic matter content (Adeli et al., 2008; Singh et al., 2009), increased soil water retention and infiltration (Kingery et al., 1994), increased soil pH (Zhang, 1998), improved soil physical, chemical and biological properties (Nyakatawa et al., 2001; Friend et al., 2006; McGrath et al., 2009), and improved crop yields of, e.g., corn, soybean, cotton, and pastures (Wood et al., 1996; Sistani et al., 2004; Adeli et al., 2005; Mitchell \& Tu, 2005).

However, little is known about the PL decomposition rate and nutrient release to the soil and the data available are mostly from abroad, complicating data comparison, mainly because these parameters are strongly influenced by climatic conditions (temperature, humidity, $\mathrm{pH}$, and soil nutrients), substrate quality, and by soil biological processes (Paul \& Clark, 1996). According to the CQFSRS/SC, (2004), the availability of N, P and $\mathrm{K}$ for the first crop is around 50, 80 and $100 \%$, respectively, and $20 \%$ of the $\mathrm{N}$ and $\mathrm{P}$ initial nutrient contents in the poultry litter is available for the second crop, although the PL dynamics and nutrient release over time are not detailed in this work. 
The objective of this study was to monitor the poultry litter decomposition and release rates of the nutrients $\mathrm{N}, \mathrm{P}, \mathrm{K}$, and $\mathrm{Ca}$ in the field for one year.

\section{MATERIAL AND METHODS}

The experiment was carried out in 2009/10 on a farm in Coronel Vivida, PR $\left(25^{\circ} 07^{\prime} \mathrm{S}\right.$ and $52^{\circ} 41^{\prime} \mathrm{W}$, $730 \mathrm{~m}$ asl). The regional climate is subtropical humid, according to the Köppen classification (Maak, 1968), and the soil at the experimental site was classified as Oxisol. The experiment was arranged in a complete randomized block design with three replications.

During the experiment, weather data (average monthly temperature and rainfall) were recorded (Figure 1) (IAPAR, 2011).

The poultry litter used in this experiment was from a poultry house, after the $11^{\text {th }}$ flock cycle, from a broiler farm near the experimental field. The compost samples from the poultry house were dried $\left(55^{\circ} \mathrm{C}\right)$ to constant weight and ground $(<1 \mathrm{~mm})$ for chemical analysis. The poultry litter dry matter (DM) content was $80.5 \%$ and N, P, K and Ca contents were $25 ; 17.6 ; 37.3$; and $44.1 \mathrm{~g} \mathrm{~kg}^{-1}$ DM, respectively.

Poultry litter levels were defined to ensure a supply of $0,100,200$ and $300 \mathrm{~kg} \mathrm{ha}^{-1} \mathrm{~N}$. Based on the poultry litter DM percentage and $\mathrm{N}$ content, the amount of PL necessary to supply these amounts of $\mathrm{N}$ was calculated (Table 1).

Sub-samples of the dried material (75 g) were placed in $20 \times 20 \mathrm{~cm}$ litter bags of $0.1 \mathrm{~mm}$ mesh. Three replications of litter bags per period were evaluated, resulting in a total of 39 litter bags of the entire experiment (13 incubation periods $\mathrm{x} 3$ replications). The litter bags were hemmed on a sewing machine, placed on the soil surface on October $18^{\text {th }}$ and collected after field incubation (periods of 15, 30, 60, 90, 120, 150, 180, 210, 240, 270, 300, 330 and 365 days).

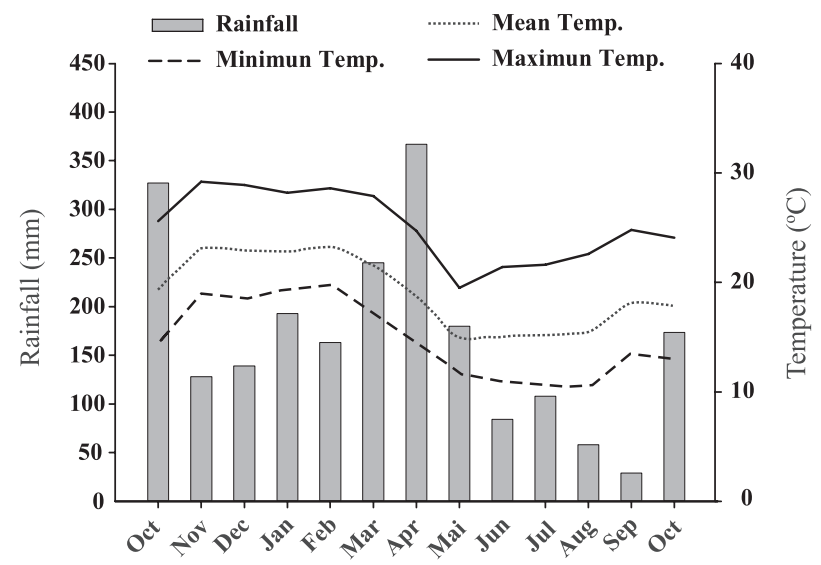

Figure 1. Average, minimum and maximum temperatures and rainfall data during the experimental period of 2009/2010 (IAPAR, 2011).

After each incubation period, three litter bags were collected, oven-dried $\left(55{ }^{\circ} \mathrm{C}\right)$ and weighed. After DM weighing, the remaining PL biomass was ground in a laboratory knife mill (ThomasWiley laboratory mill, < 40 mesh) and sulfurdigested to determine the total $\mathrm{N}$ by the Kjeldahl method (Tedesco et al., 1995). Then, the total P, $\mathrm{K}$ and Ca levels of a sub-sample obtained in the digestion were determined by spectrophotometry, flame spectrophotometry and atomic absorption spectrophotometry, respectively.

The percentage of remaining biomass and nutrients was calculated on the basis of the total biomass and total nutrient concentration at the beginning and end of the incubation periods. From the differences between DM weight and nutrient contents between incubation periods, the decomposition rate and nutrient release were determined and converted to percentage.

To describe the decomposition and nutrient release rates, the percentage of the remaining dry biomass and N, P, K and Ca contents were adjusted to nonlinear models, used to fit the decay curves by the statistical program Statgraphics Plus 4.1.

Table 1. Poultry litter dry matter $\left(\mathrm{t} \mathrm{ha}^{-1}\right)$ and respective values of $\mathrm{N}, \mathrm{P}, \mathrm{K}$ and $\mathrm{Ca}\left(\mathrm{kg} \mathrm{ha}^{-1}\right)$ applied to the soil

\begin{tabular}{crrrrr}
\hline Litter DM & Litter & N & P & K & Ca \\
\hline & & & & & \\
\cline { 4 - 6 } $\mathrm{tha} \mathrm{ha}^{-1}$ & & 100 & 70.46 & 148.70 & 176.05 \\
7992 & 4953 & 200 & 140.92 & 297.41 & 352.10 \\
11976 & 9906 & 300 & 211.38 & 446.11 & 528.14 \\
\hline
\end{tabular}


Single and double exponential models are described by equations 1 and 2 (Wieder \& Lang, 1982).

$$
\begin{gathered}
\mathrm{RDM} \text { and } \mathrm{RN}=A e^{-k a t}+(100-A) \\
\mathrm{RDM} \text { and } \mathrm{RN}=A e^{-k a t}+(100-A) e^{-k b t}
\end{gathered}
$$

where RDM is the remaining dry matter and RN the remaining nutrients after time $t$ (days), and $k a$ and $k b$ are the decay constants of the easily decomposable compartment $(A)$ and of the more recalcitrant compartment $(100-A)$, respectively. The exponential model with the highest coefficient of determination $\left(\mathrm{R}^{2}\right)$ was chosen, indicating the degree of association between the fitted model and the observed values.

Both models assume that the litter DM and nutrients can be divided into two compartments. In the asymptotic model (equation 1), only the most easily decomposable compartment $(A)$ is transformed, decreasing exponentially with time at a constant rate. The DM and nutrients of the second compartment $(100-A)$ are considered more recalcitrant and therefore, not transformed in the considered time period. In the double exponential model (equation 2), the DM and nutrients of both compartments decrease exponentially at constant rates. The first compartment $(A)$ is converted at higher rates than the second (100 - $A$ ), which is more resistant to decomposition.

From the DM and nutrient decay constant values for each compartment, its half-life $\left(t^{1 / 2}\right)$ was calculated, or in other words, the time until $50 \%$ of the compartment is decomposed. An equation proposed by Paul \& Clark (1996) was used for this purpose:

$$
\mathrm{t}_{1 / 2}=0.693 / k_{(a, b)}
$$

Based on the model adjusted for the remaining amounts of $\mathrm{N}, \mathrm{P}, \mathrm{K}$ and $\mathrm{Ca}$, the accumulative nutrient release during the evaluation period was estimated by multiplying the percentage of nutrient release of each period by the initial amount $\left(\mathrm{kg} \mathrm{ha}^{-1}\right)$ added to the soil.

\section{RESULTS AND DISCUSSION}

The N, P, K and Ca contents in the poultry litter (PL) DM were, respectively, 25; 17.6; 37.2; 44.1 , and $10.7 \mathrm{~g} \mathrm{~kg}^{-1}$. These levels were lower than the $\mathrm{N}$ and $\mathrm{P}$ levels reported by CQFSRS/SC. (2004), of 38 and $40 \mathrm{~g} \mathrm{~kg}^{-1}$, respectively. Zhang et al. (2002) evaluated 240 PL samples and found average values of $28.5,27.6$ and $23 \mathrm{~g} \mathrm{~kg}^{-1}$ for $\mathrm{N}, \mathrm{P}$ and $\mathrm{K}$. The authors also reported a moisture content of $23 \%$ and a $\mathrm{pH}$ of 7.1. These differences in litter quality or nutrient concentration are explained by the different number of poultry flocks grown on the same litter, substrate quality (material used as bed for the birds such as wood shavings, rice hulls or sawdust) and by differences in climatic conditions.

The PL dry matter decomposition and nutrient release followed a double exponential model (equation 2), so both $k a$ and $k b$ decay constants were evaluated. Decomposition in the initial periods was rapid followed by a slower phase. The DM mass loss rates were highest in the first 30 days, when $35 \%$ of the litter DM was decomposed (Figure 2). Gale $\&$ Gilmour (1986) reported that $40 \%$ of the PL dry matter was decomposed within 35 days.

Organic matter decomposition is influenced by the chemical composition of the decomposing material and soil characteristics (Douglas \& Magdoff, 1991), ratios of chemical components such as C to N (Gordillo \& Cabrera, 1997) and hemicellulose to N (Lupway \& Haque, 1998) and N concentration (Gordillo \& Cabrera, 1997). These parameters were all correlated with rates of organic $\mathrm{C}$ or $\mathrm{N}$ mineralization.

In the short term, decomposition rates were high due to the high content of readily decomposable components such as sugars, aminoacids and proteins. In the later stages, decomposition rates tended to decrease due to the accumulation of recalcitrant components such as lignin, tannins and cellulose (Heal et al., 1997; Giacomini et al., 2003; Lupwayi et al., 2007). Associated with microbial decomposition, the rainfall $(203 \mathrm{~mm})$ of the first 30 days after litter incubation in the field may have increased the decomposition rate (Figure 1).

The remaining dry matter (RDM) of $27.5 \%$ after 365 days of litter bag incubation in the field confirmed the long-term residual effect of PL in the soil (Figure 2).

The easily decomposable compartment of PL dry matter (A) represented $37.7 \%$ of the total and consequently, the recalcitrant compartment represented $62.3 \%$ of the litter; the $k a$ and $k b$ decay constants were 0.0416 and $0.0023 \mathrm{~d}^{-1}$ and the halflife 16.6 and 299 days, respectively (Table 2).

The half-life of the labile $\mathrm{N}$ compartment ( $A=17.8 \%$ ) was 9.7 days, i.e., $50 \%$ of this compartment was released in this period. Considering the litter application to supply $100 \mathrm{~kg} \mathrm{ha}^{-1} \mathrm{~N}, 17.8 \%$ of this total amount is present in the labile compartment (A) and $8.9 \mathrm{~kg} \mathrm{~N}$ will be available 9.7 days after litter application. The remaining $82.2 \mathrm{~kg} \mathrm{~N}$ will be available at slower rates, and after 166 days of field incubation, another $41.1 \mathrm{~kg}$ will be released 


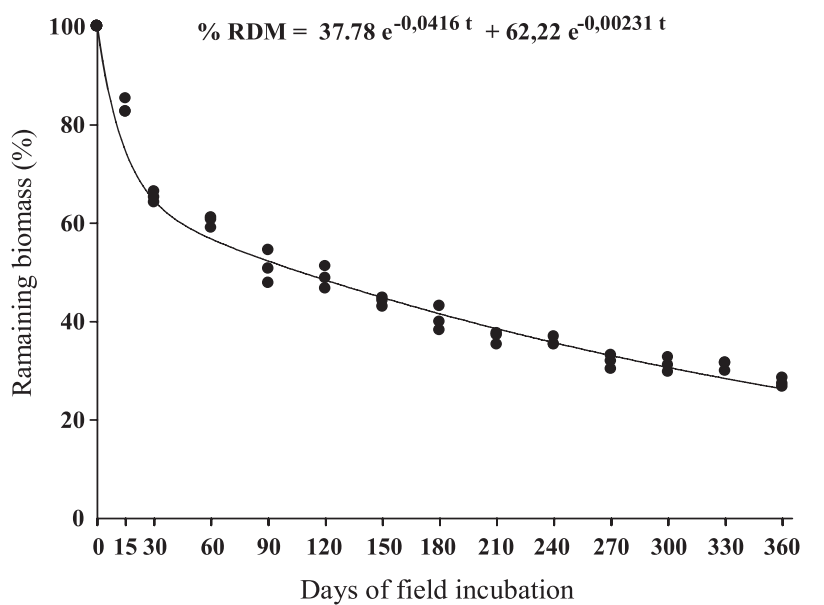

Figure 2. Remaining poultry litter dry matter (\%) after periods up to one year of field incubation in litter bags.

to the soil. It is important to highlight that in the case of $\mathrm{K}$, the percentage of the labile compartment $(80.9 \%)$ is greater and the constant release is also higher, accelerating its release. Considering the same previous simulation for $\mathrm{K}$, it is possible to infer that 60 and $180 \mathrm{~kg} \mathrm{~K}$ had been released to the soil within the first three days after PL application of 4.953 and $14.860 \mathrm{~kg} \mathrm{ha}^{-1}$ to the field, respectively.

The cycle of $\mathrm{K}$ is simpler and faster than of $\mathrm{N}$ and $\mathrm{P}$, mainly because $\mathrm{K}$ is not part of any organic compound (Marschner, 1995). Furthermore, the $\mathrm{K}$ decay rate is mainly determined by rainfall (Giacomini et al., 2003) during the decomposition process. Giacomini et al. (2003) evaluated the K release from vetch and radish residues and reported that 90 and $85 \%$ of $\mathrm{K}$ had already been released at the time of the first litter bag sampling, 15 days after distribution in the field, demonstrating the rapid release to the soil. The same was observed for PL, since 84 and $91 \%$ of $\mathrm{K}$ litter content had been released 15 and 30 days after placing the litter bags in the field (Figure 3). Rainfall occurred shortly after the litter bag incubation in the field and concentrated rainfall in the first $15(130 \mathrm{~mm})$ and 30 days $(203 \mathrm{~mm}$ ) may have increased the $\mathrm{K}$ release rate to the soil.

Exchangeable $\mathrm{K}$ is very mobile in the soil and prone to leaching, but Ayarza (1988) found K losses in tropical pastures at high application rates (300 kg ha-1 K) only, even under high rainfall. Thus, it is suggested that $\mathrm{K}$ in tropical soils is almost solely retained by cation exchange reactions.

Nitrogen and $\mathrm{P}$ in poultry litter is mainly available in organic forms (>90 and $60 \%$ respectively) and therefore, much of the $\mathrm{P}$ and $\mathrm{N}$ is not immediately available to plants (Edwards \& Daniel, 1992). Inorganic $\mathrm{N}$ and $\mathrm{P}$ can be easily extracted and measured, but organic $\mathrm{N}$ and $\mathrm{P}$ undergo a mineralization process, which is more difficult to measure. In 60 samples of broiler litter, Qafoku et al. (2001) reported $\mathrm{N}$ concentrations from 23.8 to $47 \mathrm{~g} \mathrm{~kg}^{-1} \mathrm{~N}$, and inorganic $\mathrm{N}$ concentrations ranging from 1.38 to $13.4 \mathrm{~g} \mathrm{~kg}^{-1} \mathrm{~N}$. Expressed as percentage of the organic $\mathrm{N}$ present in the litter, potential mineralizable $\mathrm{N}$ varied from 24.5 to $78.6 \%$ $($ mean $=52.5 \%)$. Kpomblekou $(2006)$ showed that inorganic $\mathrm{N}$ represents a small part of total $\mathrm{N}$ in PL samples and Adeli et al. (2005) stated that $98 \%$ of the inorganic $\mathrm{N}$ of the litter was ammonium with $2 \%$ nitrate $\mathrm{N}$.

At the first sampling 15 days after the distribution of litter bags on the field, $16.2 \%$ of the poultry $\mathrm{N}$ had been released to the soil, and $39.5 \%$ after 30 days. Gale \& Gilmour (1986) observed about $10 \%$ net $\mathrm{N}$ mineralization for PL after 28 days of field incubation. Castellanos \& Pratt (1981) observed a $\mathrm{N}$ release of about $48 \%$ from PL incubated for 10 weeks. Singh et al. (2009) reported that about $46 \%$ of the $\mathrm{N}$ from PL was released after 60 days of incubation. In another study, Qafoku et al. (2001)

Table 2. Parameters of double-exponential decomposition model fitted to the measured dry matter values, $\mathrm{N}, \mathrm{P}, \mathrm{K}$, and Ca remaining in the litter; decay constants ( $k a$ and $k b)$; half-life $\left(\mathrm{t}_{1 / 2}\right)$ of each compartment and coefficient of determination $\left(R^{2}\right)$ for the fitted model

\begin{tabular}{|c|c|c|c|c|c|c|}
\hline \multirow{2}{*}{ Variable } & \multirow{2}{*}{ A } & \multirow{2}{*}{$\mathbf{k}_{\mathrm{a}}$} & \multirow{2}{*}{$\mathbf{k}_{\mathrm{b}}$} & \multicolumn{2}{|c|}{$t_{1 / 2}$} & \multirow{2}{*}{$\mathbf{R}^{2}$} \\
\hline & & & & A & $(100-A)$ & \\
\hline Material & $\%$ & 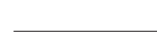 & $-\mathrm{d}$ & & ـ & \\
\hline Litter DM & 37.78 & 0.0416149 & 0.0023162 & 16.65 & 299.2 & 0.98 \\
\hline Nitrogen & 17.81 & 0.0714002 & 0.0041590 & 9.70 & 166 & 0.98 \\
\hline Phosphorus & 14.14 & 0.0851037 & 0.0038623 & 8.14 & 179 & 0.99 \\
\hline Potassium & 80.98 & 0.2329260 & 0.0207957 & 2.97 & 33.3 & 0.99 \\
\hline Calcium & 31.97 & 0.0537513 & 0.0023065 & 12.9 & 300 & 0.99 \\
\hline
\end{tabular}



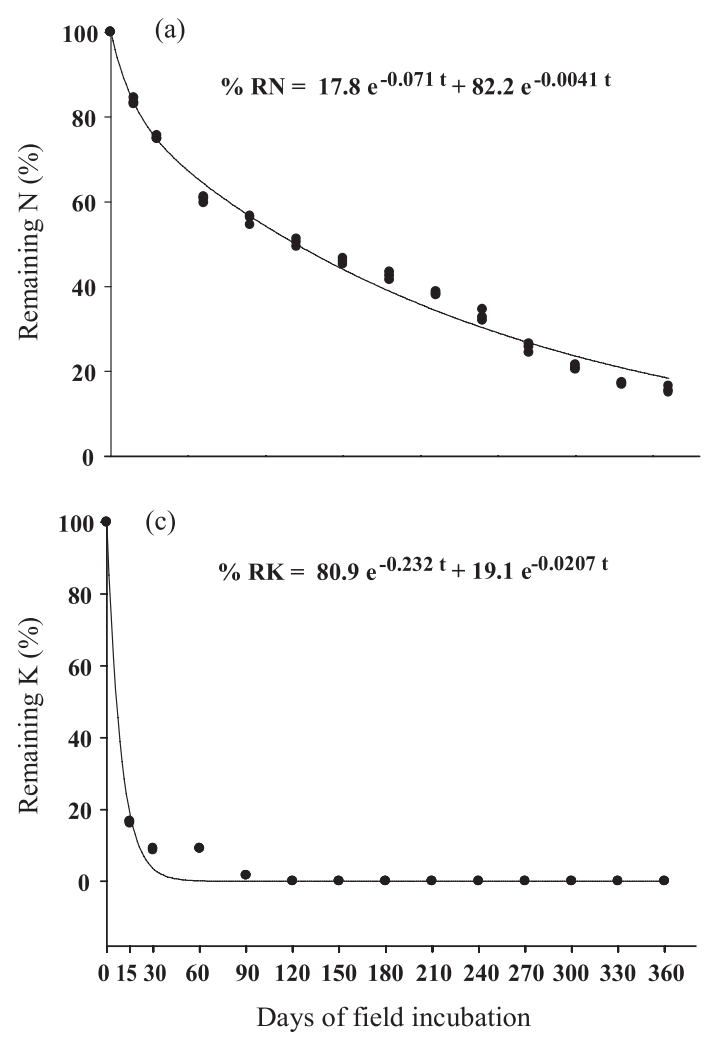
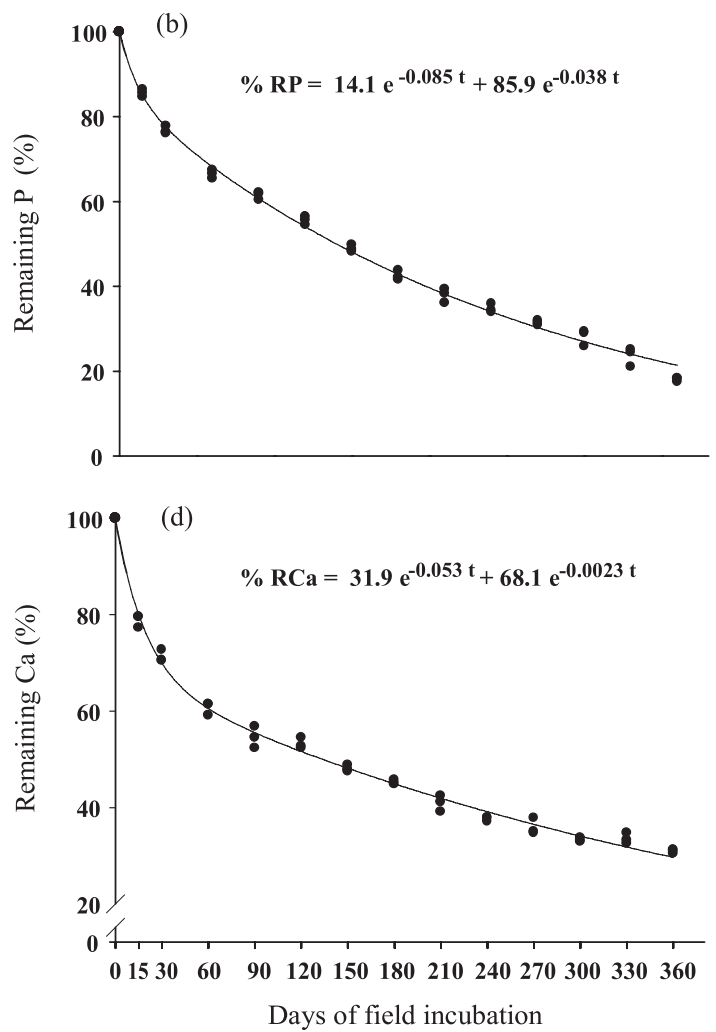

Figure 3. Remaining (\%) nitrogen (a), phosphorous (b), potassium (d) and calcium (d) in poultry litter after periods up to one year of field incubation in litter bags.

reported a mean value of $51 \%$ net $\mathrm{N}$ mineralization (range 24-74 \%) for 60 PL samples incubated for 112 days. Evers (1999) estimated that about $60 \%$ of $\mathrm{N}$ in PL would be available in the first year and the rest would increase residual fertility. In all cases there was an initial, fast release of $\mathrm{N}$ followed by a slower rate of mineralization. The heterogeneity in chemical composition (number of bird flocks, material used as litter) of the PL and the differences in climatic conditions may help explain the different nutrient mineralization rates among experiments.

After 365 days, the $\mathrm{N}$ released corresponded to $85 \%$ of the initial content, showing the long-term residual effect of poultry litter. Gordillo \& Cabrera (1997) reported an $\mathrm{N}$ mineralization rate of $90 \%$ from PL after a year of assessment. Bitzer \& Sims (1988) claimed that $67 \%$ of organic $\mathrm{N}$ in the litter was mineralized in the first year. Evers (1999) estimated that only $60 \%$ of the poultry litter $\mathrm{N}$ would be available in the first year.

Phosphorus release is much more related to $\mathrm{P}$ content and soluble $\mathrm{P}$ in the residues and to the effective action of microorganisms on the organic fractions than to the rainfall amounts (Giacomini et al., 2003). The easily decomposable $\mathrm{P}$ compartment was $14.1 \%$ and the half-life 8.1 and 179 days, respectively, of the labile and recalcitrant compartments (Table 1). After 30 days of bag incubation in the field, $23 \%$ of $\mathrm{P}$ had been released and this amount increased to 33.5 and $38.5 \%$ after 60 and 90 days of field incubation, respectively. For Singh et al. (2009), the release of P from PL occurred mainly during the first 20 days after incubation, accounting for $15-17 \%$ of the total P. Furthermore, these authors reported a residual effect of PL in an order of $30 \mathrm{~kg} \mathrm{ha}^{-1} \mathrm{~N}$ and $13 \mathrm{~kg} \mathrm{ha}^{-1} \mathrm{P}$ for the crop (wheat) following the $5 \mathrm{Mg} \mathrm{ha}^{-1} \mathrm{PL}$ fertilization of the prior crop (rice). Inorganic $\mathrm{P}$ is rapidly released to the soil after residue application, although in the later stages of decomposition, $\mathrm{P}$ is released more slowly from residues by mineralization of organic forms. After 90 days, the $\mathrm{P}$ release rate decreased, probably due to exhaustion of the inorganic $\mathrm{P}$ and labile organic $\mathrm{P}$ fractions, leaving only non-labile organic $\mathrm{P}$ fractions.

In relation to $\mathrm{Ca}$, few studies address the dynamics of its release. Despite showing a higher concentration in the labile compartment than $\mathrm{P}$ and $\mathrm{N}$ and a release rate similar to these nutrients, the release rates of $\mathrm{Ca}$ from the recalcitrant compartment was slower and the half-life 300 days. Its release was faster in the initial phase and tended to stabilize. After 365 days, $70 \%$ of the initial $\mathrm{Ca}$ content had been released. Almeida (2009) evaluated the Ca release rate from Crotalaria + corn residues and reported that the single decay model 
fitted best and a long half-life of this nutrient (139 days). The author also reported that the release rate of Ca was the slowest of the nutrients assessed.

In southern Brazil, few studies have addressed PL dynamics and nutrient release, and the available studies are not detailed in terms of nutrient release over time. However, according to CQFSRS/SC. (2004), the availability of N, P and K for the first crop is around 50, 80 and $100 \%$ and around $20 \%$ of the initial content for $\mathrm{N}$ and $\mathrm{P}$ for the second crop.

After a period of 150 days, the data demonstrated a release rate of 54, 51 and $100 \%$, respectively, for $\mathrm{N}, \mathrm{P}$ and $\mathrm{K}$, which increased to 84.3 and $82 \%$, respectively, for $\mathrm{N}$ and $\mathrm{P}$ after 365 days of field incubation. This allows the conclusion that the residual effect of PL lasts longer than a year. Litter surface application in no-tillage systems may be responsible for the slow mineralization throughout the year. For Eghball et al. (2004), PL application can increase the soil concentrations of nutrients and organic matter and its residual effects on crop production and soil properties can last for several years after PL applications ceases, providing nutrients and liming effects for the following growing seasons. It is therefore suggested that the fertilizer recommendation based on soil analysis should consider the residual effects of PL, possibly indicating a reduction in fertilizer application rates in the year after PL application.
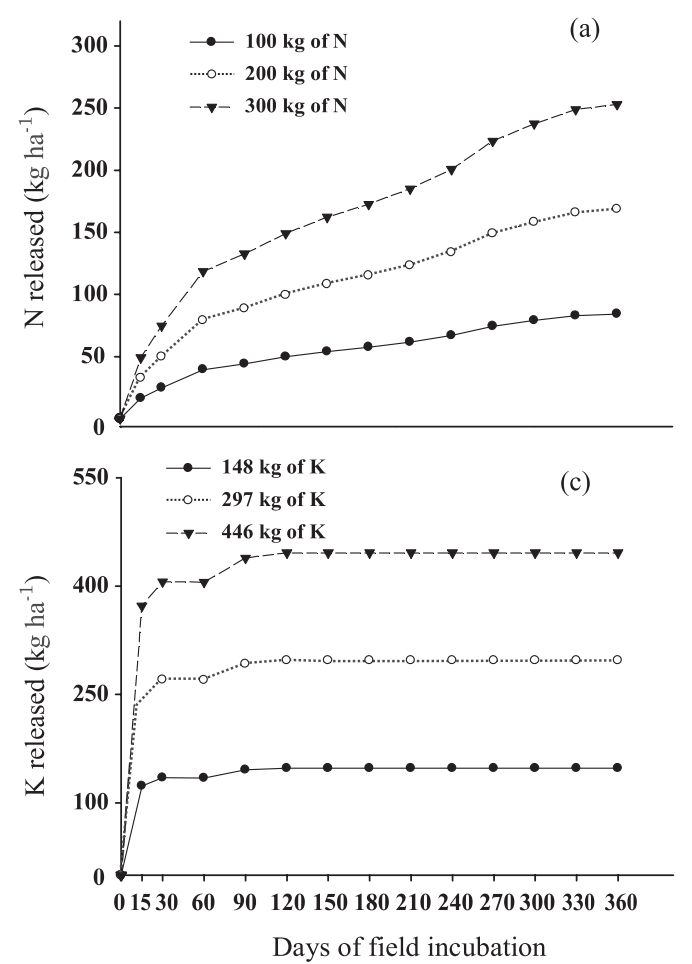

Traditionally, the application of PL has been based on crop target yields and on crop $\mathrm{N}$ requirements. To meet these objectives, high PL levels (10-15 $\mathrm{Mg} \mathrm{ha}^{-1}$ ) are applied, which can cause nutritional imbalance, nutrient losses and environmental problems. On the other hand, high PL levels applied as fertilizer tend to provide nutrients to the soil gradually, generating a residual effect for subsequent crops. For this reason, 4,953, 9,907 and $14,860 \mathrm{~kg} \mathrm{ha}^{-1} \mathrm{PL}$ were applied to the soil to supply 100, 200 and $300 \mathrm{~kg} \mathrm{ha}^{-1} \mathrm{~N}$ and considering the release rates, the nutrients are accumulated over time (Figure 4).

Considering the accumulated nutrient release from PL in absolute values, it was observed that after 15 days of PL field incubation, 16.3, 10.1, 123.6 and $37.3 \mathrm{~kg} \mathrm{ha}^{-1}$ of N, P, K and Ca had already been released to the soil, and 24.9, 16.2, 134 and $50.6 \mathrm{~kg} \mathrm{ha} \mathrm{ha}^{-1}$, respectively, after 30 days, from a $\mathrm{PL}$ amount of $4.953 \mathrm{~kg} \mathrm{ha}^{-1}$. After 180 days, these values increased to $57.5 ; 40.2 ; 148$ and $96.4 \mathrm{~kg} \mathrm{ha}^{-1}$ of $\mathrm{N}, \mathrm{P}, \mathrm{K}$ and $\mathrm{Ca}$, respectively and to $84.3 ; 57.3$; 148 and $121 \mathrm{~kg} \mathrm{ha}^{-1}$ after 365 days, at the PL level of $4.953 \mathrm{~kg} \mathrm{ha}^{-1}$. These values doubled and tripled at PL fertilization rates of 9,907 and 14,860 $\mathrm{kg} \mathrm{ha}^{-1}$, respectively (Figure 4).

In comparison, the recommended fertilization levels according to CQFSRS/SC. (2004) (considering a soil with average nutrient levels) to produce
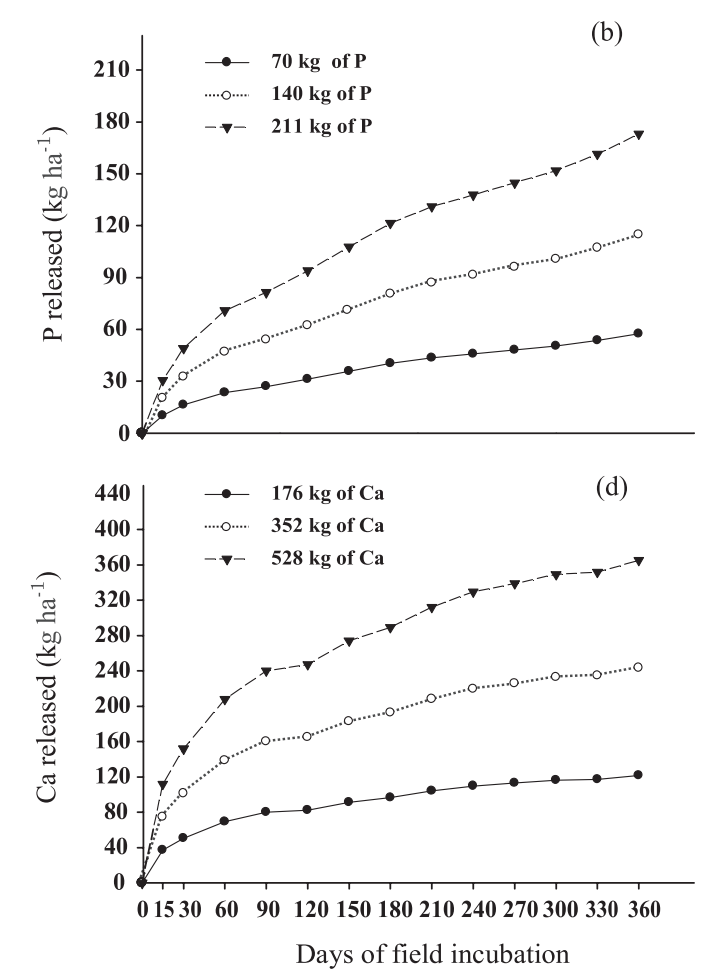

Figure 4. Accumulated release $\left(\mathrm{kg} \mathrm{ha}^{-1}\right)$ of nitrogen (a), phosphorus (b), potassium (d) and calcium (d) from poultry litter amounts $\left(4,953,9,907\right.$ and $\left.14,860 \mathrm{~kg} \mathrm{ha}^{-1}\right)$ after periods up to one year of field incubation in litter bags. 
$10 \mathrm{t} \mathrm{ha}^{-1}$ of corn and $3 \mathrm{t} \mathrm{ha}^{-1}$ of soybean grain is 150,70 and $100 \mathrm{~kg} \mathrm{ha}^{-1} \mathrm{~N}, \mathrm{P}$ and $\mathrm{K}$ for corn and 35 and $85 \mathrm{~kg} \mathrm{ha}^{-1} \mathrm{P}$ and $\mathrm{K}$ for soybean, respectively. Accordingly, the values of N, $\mathrm{P}$ and $\mathrm{K}$ released within 180 days after the PL application of $4.953 \mathrm{~kg} \mathrm{ha}^{-1}$ is sufficient to meet the soybean demand and part of the corn nutrient requirement, while higher $\mathrm{N}$ levels are needed for a $10 \mathrm{t} \mathrm{ha}^{-1}$ grain yield. If 9.907 or $14.860 \mathrm{~kg} \mathrm{ha}^{-1} \mathrm{PL}$ is applied to corn, $\mathrm{P}$ and $\mathrm{K}$ levels exceed the crop demand by 10 and $196 \mathrm{~kg} \mathrm{ha}^{-1}$ for $\mathrm{P}$ and 50 and $346 \mathrm{~kg} \mathrm{ha}^{-1}$ for $\mathrm{K}$, respectively, whereas the $\mathrm{N}$ demand is only supplied by the highest PL level. This mismanagement will always occur since the manure N/P ratios are lower than the crop N/P requirement ratio, leading to a $\mathrm{P}$ buildup in soils (Kingery et al., 1994).

Considering the data of this work, it is possible to observe that the N/P ratio is 1.42 , in other words, for each $\mathrm{kg} \mathrm{N}$, the PL contains $0.42 \mathrm{~kg} \mathrm{P}$. For Adeli et al. (2005), the N/P ratio of broiler litter averaged 1.8. Moreover, Adeli et al. (2005) reported that soybean accumulates $\mathrm{N}$ and $\mathrm{P}$ at a ratio of 10:1 and Von Pinho et al. (2009) reported that to produce $1 \mathrm{t}$ of corn grain, 22.3 and $5.3 \mathrm{~kg} \mathrm{~N}$ and $\mathrm{P}$ is necessary, respectively, corresponding to a N/P ratio of 4.2:1. Considering the soybean and corn N/P demand according to the authors, it is possible to infer that when poultry litter is used as the only $\mathrm{N}$ fertilizer source, aiming to supply $\mathrm{N}$ demand of corn, an excess application of $\mathrm{P}$ is predictable.

It is well-known that the soil $\mathrm{P}$ levels in Brazilian soils are low, frequently limiting crop yields. In this way, poultry management aimed to supply corn $\mathrm{N}$ demand could increase soil $\mathrm{P}$ content, although, $\mathrm{PL}$ corn fertilization should consider the $\mathrm{P}$ and $\mathrm{K}$ plant requirements while the $\mathrm{N}$ demand could be supplied by $\mathrm{N}$ mineral fertilizer once recent studies in the USA (Robinson \& sharpley, 1995; Sistani et al., 2004) have reported a buildup of $\mathrm{P}$ in the soil surface and environmental problems resulting from continuous PL applications, so in Brazil, a correct PL management could avoid problems like this in the future..

It is also suggested to introduce pastures in the areas that receive repeated PL applications at high levels, due to its high potential to absorb nutrients from the soil. Evaluating PL fertilization of Tifton 85, Sistani et al. (2004) observed a nutrient accumulation (average of 2 years) of 344, 58 and $472 \mathrm{~kg} \mathrm{ha}{ }^{-1}$ of $\mathrm{N}, \mathrm{P}$ and $\mathrm{K}$ from the 471,328 , and $414 \mathrm{~kg} \mathrm{ha}^{-1}$ of $\mathrm{N}, \mathrm{P}$ and $\mathrm{K}$ applied to the soil in PL (15.75 $\left.\mathrm{t} \mathrm{ha}^{-1}\right)$. The removal efficiency of these nutrients by the pasture was 73,18 , and $114 \%$, respectively. Although, despite its advantages as organic fertilizer, current restrictions established by the Brazilian Ministry of Agriculture, Livestock and Supply in a regulation of July 2009 (Brasil, 2009) on the use of poultry litter on pastures (requirement of incorporation and fallow period of 40 days) have hampered and restricted PL application to pasture in view of the difficulty of incorporating the litter, especially in no-tillage pasture areas.

Furthermore, production costs continue to increase because of the high demand for commercial fertilizers. Therefore, when farmers choose a mineral or organic fertilizer, it is important that the long-term effect of poultry litter be taken into account. Considering the nutrient amounts provided along the year by a PL application of $14,860 \mathrm{~kg} \mathrm{ha}^{-1}$ and simulating an application of mineral fertilizer by 08-12-17 NPK, 63 bags of $50 \mathrm{~kg} \mathrm{ha}^{-1}$ NPK would be necessary to supply the same amount of nutrients. Moreover, $922 \mathrm{~kg} \mathrm{KCl}$ would have to be applied to the soil to achieve the same level of $\mathrm{K}$ as released by the application of $14.860 \mathrm{~kg} \mathrm{ha}^{-1}$ poultry litter.

Robinson \& Sharpley (1995) evaluated the nutrient release under simulated rainfall $(5 \times 50 \mathrm{~min}$ rainfalls of $2.54 \mathrm{~cm} \mathrm{~h}^{-1}$ with $1 \mathrm{~h}$ intervals between rains) from a $10 \mathrm{Mg} \mathrm{ha}{ }^{-1} \mathrm{PL}$ (pine bark shavings) application, containing an average of $360 \mathrm{~kg} \mathrm{ha}^{-1} \mathrm{~N}$ and $158 \mathrm{~kg} \mathrm{ha}^{-1} \mathrm{P}$. They reported a rapid nutrient release, where $60 \%$ of the total $\mathrm{N}$ and $40 \%$ of the total $\mathrm{P}$ released during the five were lost in the first rainfall. The decrease in $\mathrm{N}$ and $\mathrm{P}$ release with consecutive rainfall was rapid, although in this period, $80 \mathrm{~kg} \mathrm{ha}^{-1} \mathrm{NH}_{4} \mathrm{~N}$ (22\% of total) and $15 \mathrm{~kg} \mathrm{ha}^{-1}$ inorganic P (10\% of total) were released from the shaving-based PL.

Under simulated rainfall, King \& Torbert (2007) evaluated $\mathrm{NO}_{3}-\mathrm{N}$ losses and observed that the $\mathrm{NO}_{3}-\mathrm{N}$ loss from PL at the first rainfall was $26 \%$. of the total loss measured in a 10 -week study. The losses generally decreased with subsequent rainfall events. Easton \& Petrovic (2004) assessed the nutrient recovered in the first runoff from turf systems also reported that the greatest loss of applied nutrients was measured in the first runoff event following application.

These high values demonstrate the rapid $\mathrm{N}$ and $\mathrm{P}$ release rate from poultry litter during the first rainfall after PL application and hence the importance of using weather forecasts to avoid litter application before heavy rains since these nutrients once released may be lost in the runoff or by leaching.

Edwards \& Daniel (1992) stress the importance of working with weather forecasts to avoid PL application before heavy rainfall. On the other hand, Chambers et al. (1997) reported that ammonia losses from surface-applied PL are commonly $15-45 \%$ of ammoniacal $\mathrm{N}$ and most of the losses occur in the first week after litter application, 
and that rainfall is highly relevant to reduce $\mathrm{N}$ losses. According to Sharpe et al. (2004), even small rainfalls $(17 \mathrm{~mm})$ immediately after PL application are very important since they reduce ammonia volatilization loss significantly, probably by transporting the $\mathrm{N}$ from the litter into the soil.

Robinson \& Sharpley (1995) evaluated the N dissolved in water after the application of $10 \mathrm{t} \mathrm{ha}^{-1}$ $\mathrm{PL}$ and reported $\mathrm{NO}_{3}-\mathrm{N}$ levels ranging from 0.2 up to $0.7 \mathrm{mg} \mathrm{L}^{-1}$. $\mathrm{NH}_{4}-\mathrm{N}$ was the major $(95 \%)$ form of $\mathrm{N}$ released allowing the conclusion that there was no $\mathrm{NO}_{3}-\mathrm{N}$ leaching. Evaluating the effect of rain (10 events) on the $\mathrm{P}$ runoff from a $13 \mathrm{t} \mathrm{ha}^{-1} \mathrm{PL}$ application, Schroeder et al. (2004) reported that only $5.7 \%$ of the total $\mathrm{P}$ applied was lost indicating that a significant portion of the applied $\mathrm{P}$ remained trapped in the soil profile.

Due to the rapid release from litter, N, P and K not taken up by plants will be potentially available for transport and soil infiltration or surface runoff by water during rainfall. Therefore, a careful timing of litter applications in the periods of active crop growth can maximize the agronomic benefit in crop nutrient uptake, while minimizing environmental impacts in losses of released nutrients by infiltration and runoff. Also, plant nutrient requirements and uptake vary during the growing season and organic fertilizers with continuous nutrient release best fit the crop nutrient requirements in the periods of active nutrient uptake. It is therefore suggested that if this synchrony is not possible for some reason (time of poultry house cleaning, crop growth stage), the poultry litter should be stored in a moisture-protected place (under a plastic or roof) since the ammonia losses from weather-exposed PL are high due to factors such as rain and high temperature (Cabrera \& Chiang, 1994), reducing the litter quality, causing environmental hazard and reducing the profit of the producer.

\section{CONCLUSIONS}

1. The nutrient release rate was highest during the first 60 days of litter decomposition.

2. Potassium was the most rapidly released nutrient from poultry litter.

3. After 150 days of litter incubation in the field, 54, 51, 100 , and $52 \%$ of N, P, K and Ca had become available to the soil. After 365 days, these values increased to 84, 82 and $70 \%$ respectively, of $\mathrm{N}, \mathrm{P}$ and $\mathrm{Ca}$.

4. The residual effects of and nutrient release from poultry litter decomposition last longer than a year.

\section{LITERATURE CITED}

ADELI, A.; SISTANI, K.R.; ROWE, D.E. \& TEWOLDE, H. Effects of broiler litter on soybean production and soil nitrogen and phosphorus concentrations. Agron. J., 97:314321, 2005.

ADELI, A.; SHANKLE, M.W.; TEWOLDE, H.; SISTANI, K.R. \& ROWE, D.E. Nutrient dynamics from broiler litter applied to no-till cotton in an upland soil. Agron. J., 100:564-570, 2008 .

ALMEIDA, K. Adubos verdes na produção de alface e cenoura sob sistema orgânico. Botucatu, Faculdade Estadual Paulista Julio de Mesquita Filho, 2009. 131p. (Tese de Doutorado)

AYARZA, M.A. Potassium dynamics in a humid tropical pasture in the Peruvian Amazon. Raleigh, North Carolina State University, 1988. (Tese de Doutorado)

BITZER, C.C. \& SIMS, J.T. Estimating the availability of nitrogen in broiler litter through laboratory and field studies. J. Environ. Qual., 17:47-54, 1988.

BRASIL - Ministério da Agricultura, Pecuária e Abastecimento. Instrução normativa n. 25, de 23 de Julho de 2009. Normas sobre as especificações e as garantias, as tolerâncias, o registro, a embalagem e a rotulagem dos fertilizantes orgânicos simples, mistos, compostos, organominerais e biofertilizantes destinados a agricultura. Diário Oficial da União, 28 de julho de 2009, seção 1. p18.

CABRERA, M.L. \& CHIANG, S.C. Water content effect on denitrification and ammonia volatilization in poultry litter. Soil. Sci. Soc. Am. J., 58:811-816, 1994.

CASTELLANOS, J.Z. \& PRATT, P.F. Mineralization of manure nitrogen - Correlation with laboratory indexes. Soil Sci. Soc. Am. J., 45:354-357, 1981.

CHAMBERS, B.J.; SMITH, K.A. \& van der WEERDEN, T.J. Ammonia emissions following the land spreading of solid manures. In: JARVIS, S.C. \& PAIN, B.F., eds. Gaseous nitrogen emissions from grasslands. Oxon, CAB International, 1997. p.275-280.

COMISSÃO DE QUÍMICA E FERTILIDADE DO SOLO CQFSRS/SC. Manual de adubação e de calagem para os estados do Rio Grande do Sul e Santa Catarina. Porto Alegre, 2004. 394p.

DOUGLAS, B.F. \& MAGDOFF, F.R. An evaluation of nitrogen mineralization induces for organic residues. J. Environ. Qual., 20:368-372, 1991.

EDWARDS, D.R. \& DANIEL, T.C. Environmental impacts of farm poultry waste disposal - A review. Biores. Technol., 41:9-33, 1992.

EGHBALL, B.; GINTING, D. \& GILLEY, J.E. Residual effects of manure and compost applications on corn production and soil properties. Agron. J., 96:442-447, 2004.

EASTON, Z.M. \& PETROVIC, A.M. Fertilizer source effect on ground and surface water quality in drainage from turfgrass. J. Environ. Qual., 33, 645-655, 2004 
EVERS, G.W. Comparison of broiler poultry litter and commercial fertilizer for coastal bermudagrass production in the southeastern U.S. J. Sustainable Agric., 12:55-57, 1999.

FRIEND, A.L.; ROBERTS, S.D.; SCHOENHOLTZ, S.H.; MOBLEY, J.A. \& GERARD, P.D. Poultry litter application to Loblolly pine forests: Growth and nutrient containment. J. Environ. Qual., 35:837-848, 2006.

GALE, P.M. \& GILMOUR, J.T. Carbon and nitrogen mineralization kinetics for poultry litter. J. Environ. Qual., 15:423-426, 1986.

GIACOMINI, S.J.; AITA, C.; HÜBNER, A.P.; LUNKES, A.; GUIDINI, E. \& AMARAL, E.B. Liberação de fósforo e potássio durante a decomposição de resíduos culturais em plantio direto. Pesq. Agropec. Bras., 38:1097-1104, 2003.

GORDILLO, R.M. \& CABRERA, M.L. Waste management. Mineralizable nitrogen in broiler litter: I. Effect of selected litter chemical characteristics. J. Environ. Qual., 26:16721679, 1997.

HEAL, O.W.; ANDERSON, J.M. \& SWIFT, M.J. Plant litter quality and decomposition: An historical overview. In: CADISCH, G. \& GILLER, K.E., ed. Driven by nature: Plant litter quality and decomposition. Wallingford, CAB International, 1997. p.3-30.

INSTITUTO AGRONÔMICO DO PARANÁ - IAPAR. < http://www. iapar.br/modules/conteudo/conteudo.php?conteudo=890 > Accessado: Feb. 5 , 2011.

KING, K.W. \& TORBERT, H.A. Nitrate and ammonium losses from surface-applied organic and inorganic fertilizers. J. Agric. Sci., 145:385-393, 2007.

KINGERY, W.L.; WOOD, C.W.; DELANEY, D.P.; WILLIAMS, J.C. \& MULLINS, G.L. Impact of long-term land application of broiler litter on environmentally related soil properties. J. Environ. Qual., 23:139-147, 1994.

KPOMBLEKOU, K.A. Relative proportion of inorganic and total nitrogen in broiler litter as determined by various methods. J. Sci. Food. Agric., 86:2354-2362, 2006.

LUPWAYI, N.Z.; CLAYTON, G.W.; O’DONOVAN, J.T.; HARKER, K.N.; TURKINGTON, T.K. \& SOON, Y.K. Phosphorus release during decomposition of crop residues under conventional and zero tillage. Soil Tillage Res., 95:231-239, 2007.

LUPWAY, N.Z. \& HAQUE, Z. Mineralization of N, P, K, Ca and $\mathrm{Mg}$ from sesbania and leucaena leaves varying in chemical composition. Soil. Biol. Biochem., 30: 337-344, 1998.

MAAK, R. Geografia física do estado do Paraná. Curitiba, Banco de Desenvolvimento do Paraná, 1968. 350p.

MARSCHNER, H. Mineral nutrition of higher plants. 2.ed. San Diego, Academic, 1995. 889p.
McGRATH, S.; MAGUIRE, R.O.; TRACY, B.F. \& FIKE, J.H. Improving soil nutrition with poultry litter application in low-input forage systems. Agron. J., 102:48-54, 2009.

MITCHELL, C.C. \& TU, S. Long-Term evaluation of poultry litter as a source of nitrogen for cotton and corn. Agron. J., 97:399-407, 2005.

NYAKATAWA, E.Z.; REDDY, K.C \& BROWN, G.F. Residual effect of poultry litter applied to cotton in conservation tillage systems on succeeding rye and corn. Field Crops Res., 71:159-171, 2001.

PAUL, E.A. \& CLARK, F.E. Soil microbiology and biochemistry. San Diego, Academic Press, 1996. 340p.

QAFOKU, O.S.; CABRERA, M.L.; WINDHAM, W.R. \& HILL, N.S. Rapid methods to determine potentially mineralizable nitrogen in broiler litter. J. Environ.Qual., 30:217-221, 2001.

ROBINSON, J.S. \& SARPLEY, A.N. Release of nitrogen and phosphorus from poultry litter. J. Environ. Qual., 24:6267, 1995.

SCHROEDER, P.D.; RADCLIFFE, D.E. \& CABRERA, M.L. Rainfall timing and poultry litter application rate effects on phosphorus loss in surface runoff. J. Environ. Qual., 33:2201-2209, 2004.

SHARPE, R.R.; SCHOMBERG, H.H.; HARPER, L.A.; ENDALE, D.M.; JENKINS, M.B. \& FRANZLUEBBERS, A.J. Ammonia volatilization from surface-applied poultry litter under conservation tillage management practices. J. Environ. Qual., 33:1183-1188, 2004.

SINGH, Y.; GUPTA, R.K.; THIND, H.S.; SINGH, B.; SINGH. V.; SINGH. J. \& LADHA, J.K. Poultry litter as a nitrogen and phosphorus source for the rice-wheat cropping system. Biol. Fert. Soils., 45:701-710, 2009.

SISTANI, K.R.; BRINK, G.E.; ADELI, A.; TEWOLDE, H. \& ROWE, D.E. Year-Round soil nutrient dynamics from broiler litter application to three bermudagrass cultivars. Agron. J., 96:525-530, 2004.

TEDESCO, M.J.; GIANELLO, C.; BISSANI, C.A.; BOHNEN, H. \& VOLKWEIS, S.J. Análise de solo, plantas e outros minerais. Porto Alegre, Universidade Federal do Rio Grande do Sul, 1995. 174p.

VON PINHO, RG.; BORGES, I.D.; PEREIRA, J.L.A.R. \& REIS, M.C. Marcha de absorção de macronutrientes e acúmulo de matéria seca em milho. R. Bras. Milho Sorgo, 8:157$173,2009$.

WIEDER, R.K. \& LANG, G.E. A critique of the analytical methods used in examining decomposition data from litter bags. Ecology, 63:1636-1642, 1982.

WOOD, B.H.; WOOD, C.W.; YOOQ, K.H. \& DELANEY, D.P. Nutrient accumulation and nitrate leaching under broiler litter amended corn fields. Comm. Soil. Sci. Plant. Anal., $27: 2875-2894,1996$ 
ZANCHET, M.S. Características das ocupações na Agropecuária Paranaense. Curitiba, IPARDES, 2008.

ZHANG, H. Animal manure can raise soil pH. Oklahoma: Oklahoma Cooperative Extension Service, 1998. (Production Technology, Department of Plant and Soil Sciences, v.10. n.7)
ZHANG, H.; SMOLEN, M.E. \& HAMILTON, D. Poultry litter quality criteria. Oklahoma Cooperative Extension Service, 2002. (Production technology, Department of Plant and Soil Sciences, v.14, n.24) 
